
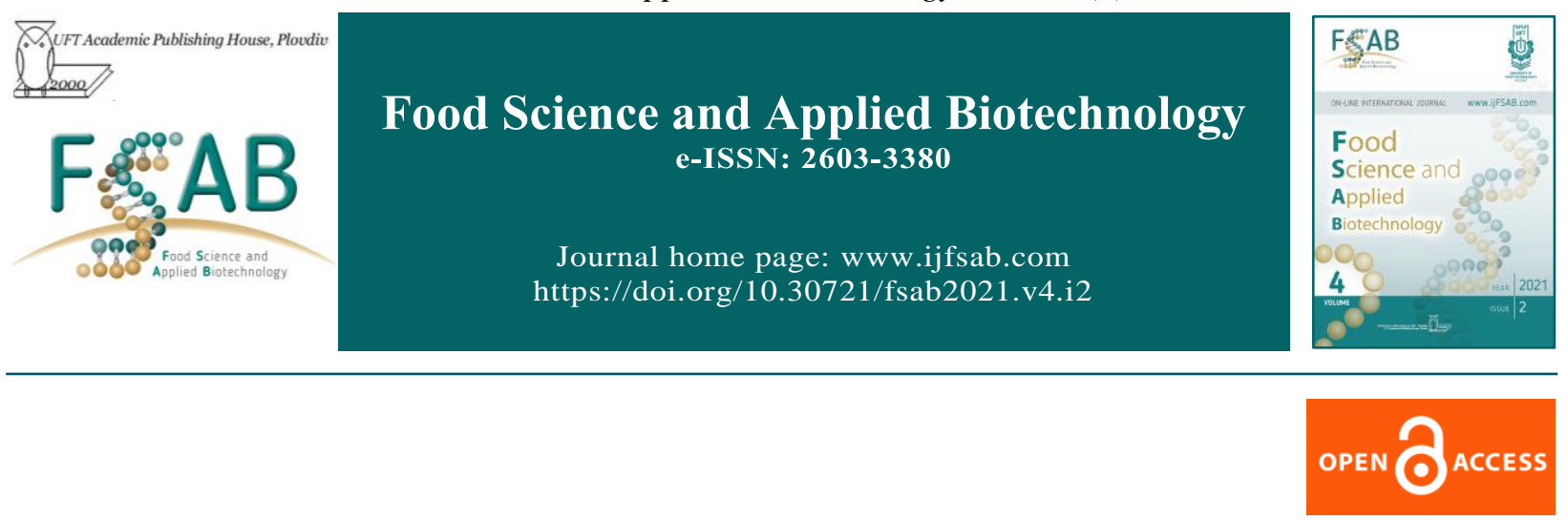

Research Article

\title{
Antibacterial and antibiofilm effects of garlic (Allium sativum), ginger (Zingiber officinale) and mint (Mentha piperta) on Escherichia coli biofilms
}

\author{
Ndaindila N.K Haindongo ${ }^{1}$, Amara Anyogu ${ }^{2}$, Osmond C. Ekwebelem ${ }^{3}$, Christian Anumudu ${ }^{1}$, \\ Helen Onyeaka ${ }^{1 \square}$ \\ ${ }^{1}$ School of Chemical Engineering, University of Birmingham, United Kingdom \\ ${ }^{2}$ School of Life Sciences, University of Westminster, London, United Kingdom \\ ${ }^{3}$ Faculty of Biological Sciences, University of Nigeria, Nsukka, Nigeria
}

\begin{abstract}
Biofilms are a significant concern in the food industry because of their potential to enhance bacterial survival and cause foodborne outbreaks. Escherichia coli $(E$. coli) is among the leading pathogens responsible for foodborne outbreaks and this can be attributed to its ability to form biofilms in food containers and food preparatory surfaces. The purpose of this study was to investigate the antibacterial and antibiofilm properties of garlic, ginger and mint and their potential to inhibit E.coli and biofilm formation. Disc diffusion assays and 96-well plate crystal violet-based methods were used to achieve these objectives. The plant extracts were diluted from $1 \mathrm{mg} / \mathrm{ml}$ to $0.1 \mathrm{mg} / \mathrm{ml}$ and incubated $25^{\circ} \mathrm{C}$ and $37^{\circ} \mathrm{C}$ to investigate the antimicrobial and antibiofilm effects on E. coli. The findings of this study showed that low temperatures induced the formation of $E$. coli biofilms and all tested extracts contain a broad spectrum of antibacterial and antibiofilm properties. This study provided new insights on the combined antimicrobial and antibiofilm properties of garlic, ginger and mint against planktonic cells and biofilms of E. coli MG 1655 and highlight the potential use of these extracts in the food industry to prevent biofilm formation by E. coli.
\end{abstract}

Keywords: spices, antibacterial, antibiofilm, biofilms, Escherichia coli (E. coli)

Abbreviations: BIC - biofilm inhibitory concentration; CFU - colony forming units; HACCP - hazard analysis critical control points; MIC - minimum inhibitory concentration; OD - optical density; PBS phosphate buffer solution; TTO - tea tree oil

${ }^{\square}$ Corresponding author: Dr Helen Onyeaka, School of Chemical Engineering, University of Birmingham Tel: +44 1214145 292,E-mail: h.onyeaka@bham.ac.uk

\section{Article history:}

Received 19 April 2021

Reviewed 26 May 2021

Accepted 31 August 2021

Available on-line 10 October 2021 https://doi.org/10.30721/fsab2021.v4.i2.146 (C) 2021 The Authors. UFT Academic publishing house, Plovdiv 


\section{Introduction}

Food safety is a basic need and everyone's concern. Assurance of food safety is important to reduce foodborne illnesses, spoilage, and economic losses. A variety of challenges encompassing physical, chemical and biological challenges are associated with delivering safe food from the farm to the fork. Food microorganisms are of particular interest because they cause spoilage, making food undesirable and unsafe for human consumption. Microorganisms and biofilms are among the most common cause of foodborne diseases and deaths around the world. Biofilms are defined as an assemblage of surface-associated microbial cells enclosed in an extracellular polymeric substance (Donlan 2002; Ryu et al. 2004; Simões et al. 2010). When bacteria are in a biofilm, they compromise sanitation standards; damages equipment and cause fouling in condensers and heat exchanger tubes, resulting in energy loss (Trachoo 2003).

Given that biofilms have become a threat to human health, food safety needs to be of great interest to key players in the food industry (Galie et al. 2018). Foodborne illnesses may arise from the consumption of food contaminated by pathogenic bacteria. These bacteria can get into the food from various sources, including the food itself, washing water, food preparation environment, and biofilms. Even though foodborne diseases are a vital cause of mortality and morbidity, and a significant obstacle to socioeconomic development worldwide, the full extent and burden of unsafe food remain unknown (WHO, 2015).

It is vital to employ and explore all possible solutions to prevent biofilms' growth in the food industry. Due to consumer concerns about food safety and more natural products, there has been a growing interest in using natural antibacterial products for the control of biofilms as chemical agents may leave residues on food preparation surfaces that can be incorporated into the foods during packaging. Interestingly, the most common and well-researched compounds originate from plants. Plants have been used for medicinal purposes and their antimicrobial properties (Bazargani and Rohloff 2016) and more recently including potential activity against biofilm formation (Cos et al. 2010; Nostro et al. 2016). Plant extracts have a widespread application in the pharmaceutical industry because they contain various bioactive compounds with antimicrobial properties. Biofilm inhibitory effects of plant extracts have been reported against $E$. coli (John et al. 2013) Listeria monocytogenes ( $L$. monocytogenes) (Sandasi et al. 2010) Staphylococcus aureus (S. aureus) (Bazargani and Rohloff 2016) and Candida albicans (C. albicans) (Agarwal et al. 2008). As a result, these extracts have gained extensive research interests in both industry and academia.

E. coli is among the most frequent causes of foodborne illnesses. Various veritable findings have described the ability of $E$. coli to attach to surfaces resulting in biofilm formation (Ryu and Beuchat 2005; Mendonça et al. 2012). Significantly, it has been hypothesised that this contributes to the increase of $E$. coli in foodborne outbreaks (Shi and Zhu 2009). Therefore, there is a need to explore measures that will inhibit biofilm formation. Several studies have researched the antimicrobial properties of plant extracts against various microorganisms, including wild strains of $E$. coli (Shilpa and Thomas 2010; Gull et al. 2012; Al-Sum and Al-Arfaj 2013). However, there are limited studies on plant extracts' antibiofilm properties against the $E$. coli wild-type laboratory strains, such as E. coli MG-1655. These facts gave impetus to this research. Hence, this research was designed to study the antibacterial and antibiofilm properties of garlic, ginger and mint against the formation of $E$. coli $\mathrm{MG}-1655$ biofilms.

\section{Materials and Methods}

The bacteria used was a K-strain (MG 1655) E. coli provided by the Microbiology Laboratory, University of Birmingham, UK. The strain was stored at $4^{\circ} \mathrm{C}$ on Nutrient agar plates. Subculture was done every two weeks to maintain viability and purity. Garlic (Allium sativum), ginger (Zingiber officinale) and mint (Mentha piperta) that were used in the present study were purchased from a local market in Birmingham, United Kingdom. The food samples were organic and were prepared from their natural state. 


\section{Determination of Colony Forming Units (CFU) and Optical Density (OD)}

To determine the CFU of the $E$. coli viable cells in a sample, E. coli was plated on Nutrient Agar. The colonies were counted and the CFU was calculated using the below formula:

$\mathrm{Cfu} / \mathrm{ml}=$ number of colonies $\times$ dilution factor $\times$ dilution factor related to the amount plated

The Optical Density was carried out to determine the concentration of bacterial cells in a sample. The OD was measured at a wavelength of $600 \mathrm{~nm}$ using a spectrophotometer. This technique was carried out in accordance with (Jaglic et al. 2012). Initially, 20 $\mathrm{ml}$ of nutrient broth was transferred into $500 \mathrm{ml}$, inoculated with fresh overnight culture and incubated on the rotary shaker $\left(37^{\circ} \mathrm{C}, 150 \mathrm{rpm}\right)$. This experiment was carried out at hourly intervals for 8 and 24 hours and the $\mathrm{OD}_{600}$ was measured at each interval. Serial dilutions using Phosphate Buffer solution (PBS) were carried out and plated on nutrient agar plate. Following this, the plates were incubated for $24 \mathrm{~h}$ at $37^{\circ} \mathrm{C}$. This data was used to standardize the bacterial culture to ensure that the same amount of cultures were used in all the experiments.

\section{Preparation of Plant extracts}

The plant samples were prepared using $200 \mathrm{ml}$ distilled water and $200 \mathrm{ml}$ ethanol using separate extraction methods according to (Gull et al. 2012), with minor modifications. Fresh plant leaves were used to prepare two types of extracts, ethanol (95\% $\mathrm{v} / \mathrm{v}$ ) and water. The extracts were filtered using Jcloths, laboratory sieve with a pore size of $425 \mu \mathrm{m}$. Unlike the water extracts, the ethanol filtrates were evaporated at $50^{\circ} \mathrm{C}$ using a rotary evaporator, resuspended in 2:1 5\% acetone solution then sonicated with the Ultrasonic cleaner (MME 351). Both the water and ethanol extracts samples were first filtered with the laboratory sieve $(250 \mu \mathrm{l})$, then filtered again with the $18.5 \mathrm{~cm}$ filter paper (Whatman) to remove unwanted particles. The extracts were all centrifuged at $8000 \mathrm{rpm}$ for 15 minutes to remove undissolved residues. The extract samples were sterilised by syringe filter $(0.2$ $\mu \mathrm{l})$, and sterility was verified by plating on nutrient agar plates. The extract solutions were stored at $4^{\circ} \mathrm{C}$. Garlic water and ethanol extracts were named GaW and $\mathrm{GaE}$, ginger water and ethanol extracts as $\mathrm{GiW}$ and GiE, while mint water and ethanol extracts were named MiW and MiE.

\section{Disk Diffusion Assay}

The disk diffusion method (Bayer et al. 1966; Sarker et al. 2007), with minor modifications, was used to determine the antimicrobial activities of the extracts. To determine the concentration, the extracts were diluted, ranging from $1 \mathrm{mg} / \mathrm{ml}$ to 0.1 $\mathrm{mg} / \mathrm{ml}$ in sterile Eppendorf tubes containing nutrient broth. The $6 \mathrm{~mm}$ antimicrobial susceptibility test disks (Oxoid) were dipped into the diluted extracts for about 10 minutes and seeded over the nutrient agar plates with bacterial culture. The plates were allowed to diffuse at room temperature for approximately an hour and then incubated in the upright position at $37^{\circ} \mathrm{C}$ for 24 hours. All experiments were performed under sterile conditions, and penicillin was used as a positive control. After incubation, the inhibition zone was measured with a meter rule and results were recorded in $\mathrm{mm}$. The minimum inhibitory concentration (MIC) was the lowest concentration that showed a clear inhibition zone.

\section{Determination of minimum exposure times}

The extracts were diluted, ranging from $1 \mathrm{mg} / \mathrm{ml}$ to $0.1 \mathrm{mg} / \mathrm{ml}$ in sterile Eppendorf tubes containing nutrient broth. Next, $50 \mu \mathrm{l}$ of the standardised fresh culture was added to $50 \mu \mathrm{l}$ of the different plant extract concentrations and incubated at $25^{\circ} \mathrm{C}$ and $37^{\circ} \mathrm{C}$. This experiment was carried out at hourly intervals for 8 hours. The inoculum was withdrawn at hourly intervals, and serial dilutions were performed on this using the Phosphate Buffer solution (PBS), then plated on the nutrient agar plate.

\section{Biofilm formation assay and quantification}

The ability of E. coli to form biofilms was assayed as described by Nikolic et al. (2014). All the tests were performed in 96-well polystyrene microtitration plates. Initially, 50 $\mu$ l of fresh standardised bacterial culture was pipetted in each well and $50 \mu$ of nutrient broth was added to each well plate. The plates were placed in a sterile plastic bag with a soaking wet paper towel to prevent cell dehydration. Prior to incubation at $25^{\circ} \mathrm{C}$ and $37^{\circ} \mathrm{C}$ for 48 hours, the content of each well was gently removed by tapping the plates. The wells were washed thrice with $200 \mu$ l of sterile PBS to remove 
unbounded cells. Biofilms were then stained with $200 \mu 10.1 \%(\mathrm{w} / \mathrm{v})$ crystal violet and incubated at room temperature for 20 minutes, followed by another washing step with sterile deionised water. The plates were fixed with $200 \mu \mathrm{l}$ of $96 \%(\mathrm{v} / \mathrm{v})$ ethanol. The absorbance of stained adherent bacteria as measured at (OD620) using a microplate reader (Biochrom EZ Read 400) (Lee et al. 2013).

\section{Determination of biofilm effects}

The effects of plant extracts on biofilm formation were also analysed using the 96-well polystyrene microtitration plates. Dilutions of plant extracts were prepared in sterile Eppendorf tubes with nutrient broth, and $50 \mu \mathrm{L}$ was added to each well. The tested concentration ranged from $1 \mathrm{mg} / \mathrm{ml}$ to $0.1 \mathrm{mg} / \mathrm{ml}$. A $50 \mu \mathrm{L}$ of fresh bacterial suspension was added to each well. Controls were included in both analysis; growth control (E. coli + broth), media control (broth only) and sterility control (broth + extract). After incubation at $25^{\circ} \mathrm{C}$ and $37^{\circ} \mathrm{C}$ for 48 hours, biofilms were analysed using the above-described crystal violet staining assay.

The percentage of biofilm inhibition was calculated using the formula [(OD growth control - OD sample) / OD growth control] x 100 (Sandasi et al. 2010; Chaieb et al. 2011). As stipulated by Nikolić et al. (2014), the biofilm inhibitory concentration (BIC50) was expressed as the lowest concentration of the extract that showed $50 \%$ inhibition of the biofilm formation.

\section{Statistical Analysis}

All the experiments were carried out in duplicates. Statistical analysis was undertaken in Microsoft Excel. Data were presented as means and standard deviation shown by the error bars in the graphs.

\section{Results and Discussion}

\section{Antimicrobial activity}

As shown in Figure 1, this study illustrated that the garlic water extract had the highest antimicrobial activity when compared to the other extracts analysed. Comparatively, the studies of Gull et al. (2012); (Jang et al. 2018); and (Wolde et al. 2018) also revealed a similar pattern of the antimicrobial activity shown by garlic. Various studies (Cavallito and Bailey 1944; Ankri and Mirelman 1999; Harris et al. 2001) demonstrated and accredited that the antibacterial activities of garlic are mainly due to Allicin (Block 1985). However, the method of preparation and extraction is significant. For instance, it is speculated that Allicin is not present in garlic cloves; therefore, it has to be crushed/minced to transform Alliin to Allicin because Alliin has no antimicrobial activity (Ankri and Mirelman 1999).

The antimicrobial activity shown by the GaW in this study agrees with previous findings (O'Gara et al. 2000; Iwalokun et al. 2004; Bakht et al. 2011; Gull et al. 2012). From this standpoint, it can be considered that the high potency of GaW might have been due to its polarity. (Wolde et al. 2018) adds that the polarity of the solvent can have an effect on the number of compounds obtained. Garlic has high amounts of polar bioactive than non-polar bioactive compounds. Additionally, (Jang et al. 2018) suggests that these results might be due to the high phenol and flavonoid contents in distilled water plus. Furthermore, as reported by (Liu et al. 2014), GaW extract has higher reducing power and lower metal chelating ability than methanol/ethanol extracts. However, studies have also been reported were $\mathrm{GaE}$ displayed more antimicrobial activities (Harris et al. 2001).

In contrast with $\mathrm{GaE}$, scholars have found no inhibitory effects from GaW against E. coli (Ekwenye and Elegalam 2005). The explanation was that ethanol is an organic solvent, and it dissolved the required organic compounds necessary for antimicrobial activity. Pure Allicin is postulated to be a volatile molecule that is poorly miscible in water solutions; thus, there are no inhibitory effects (Block 1985; Ankri and Mirelman 1999). Even though different researchers through proof-of-concept experiments have shown that $\mathrm{GaE}$ has more inhibitory effects and water does not, contrarily, in this experiment, GaW exhibited the most antimicrobial properties against $E$. coli.

Furthermore, as illustrated in Figure 1, both ethanol extracts of garlic and mint were more effective than the water extracts against the tested $E$. coli strain. 


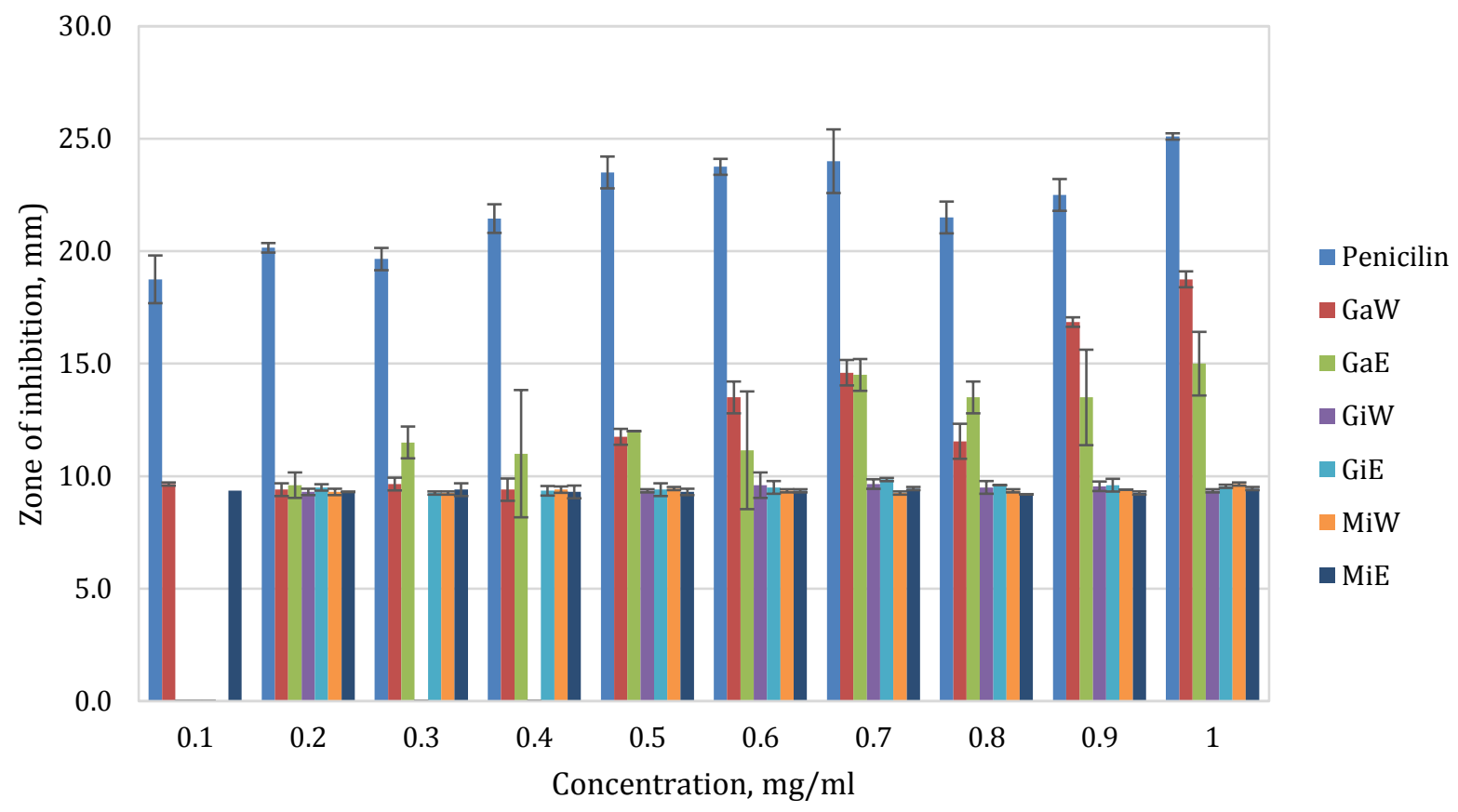

Figure 1: The inhibitory effects of water and ethanol extracts from garlic, ginger and mint $E$. coli at concentrations between $(0.1 \mathrm{mg} / \mathrm{ml}-1 \mathrm{mg} / \mathrm{ml})$.

The results of the antimicrobial effects of ginger in this study are compatible with the majority of the published studies regarding ginger and its antimicrobial properties (Natta et al. 2008; Malu et al. 2009; Gull et al. 2012). Gull et al. (2012) suggests that the antibacterial activities might be due to gingers active compound, gingerol plus, sesquiterpenoids and zingiberene. The results obtained in this study collaborate with previous findings (Sebiomo et al. 2011). The garlic ethanol extract showed the greatest effects against $E$. coli and the outcomes on the antibacterial activity of garlic are consistent with previous findings (Sivropoulou et al. 1995; Al-Sum and Al-Arfaj 2013; Singh et al. 2015). Superior results regarding the antimicrobial properties of mint were reported (Sivropoulou et al. 1995; Ceylan et al. 2014). Although our methodologies were unable to detect the differences in compounds present in these extracts, it has been widely reported that flavonoids, essential oils and active compounds are accountable for plant extracts antimicrobial properties.
The MIC of the garlic, ginger and mint extracts against $E$. coli ranged from $0.1 \mathrm{mg} / \mathrm{ml}$ to $0.2 \mathrm{mg} / \mathrm{ml}$. For an organism to be sensitive, the diameter of the zone of inhibition of the antimicrobial agent should be above $3 \mathrm{~mm}$ if it is less, it is resistant (ModarresiChahardehi et al. 2012). So, bearing this in mind and comparing the values obtained with those of the control values (Penicillin), the results revealed that all the tested extracts, with garlic being the most effective, have antimicrobial effects against $E$. coli with a diameter of zones of inhibition ranging from $9.2 \mathrm{~mm}$ to $18.8 \mathrm{~mm}$. These findings were supported by (Ekwenye and Elegalam 2005) and the findings of (Ankri and Mirelman 1999) on the sensitivity of E. coli to Allicin. This could be because, Allicin is known for its ability to penetrate cell membranes, thus, it is possible to speculate that this bacterial feature may influence the access of Allicin to periplasmic and cytoplasmic enzymes (Bakri and Douglas 2005). Additionally, the thin peptidoglycan layer in gram negatives may support the penetration of Allicin (Bakri and Douglas 2005). Thus, RNA, DNA and proteins synthesis is inhibited, affecting the growth of E. coli (Wolde et al. 2018). 


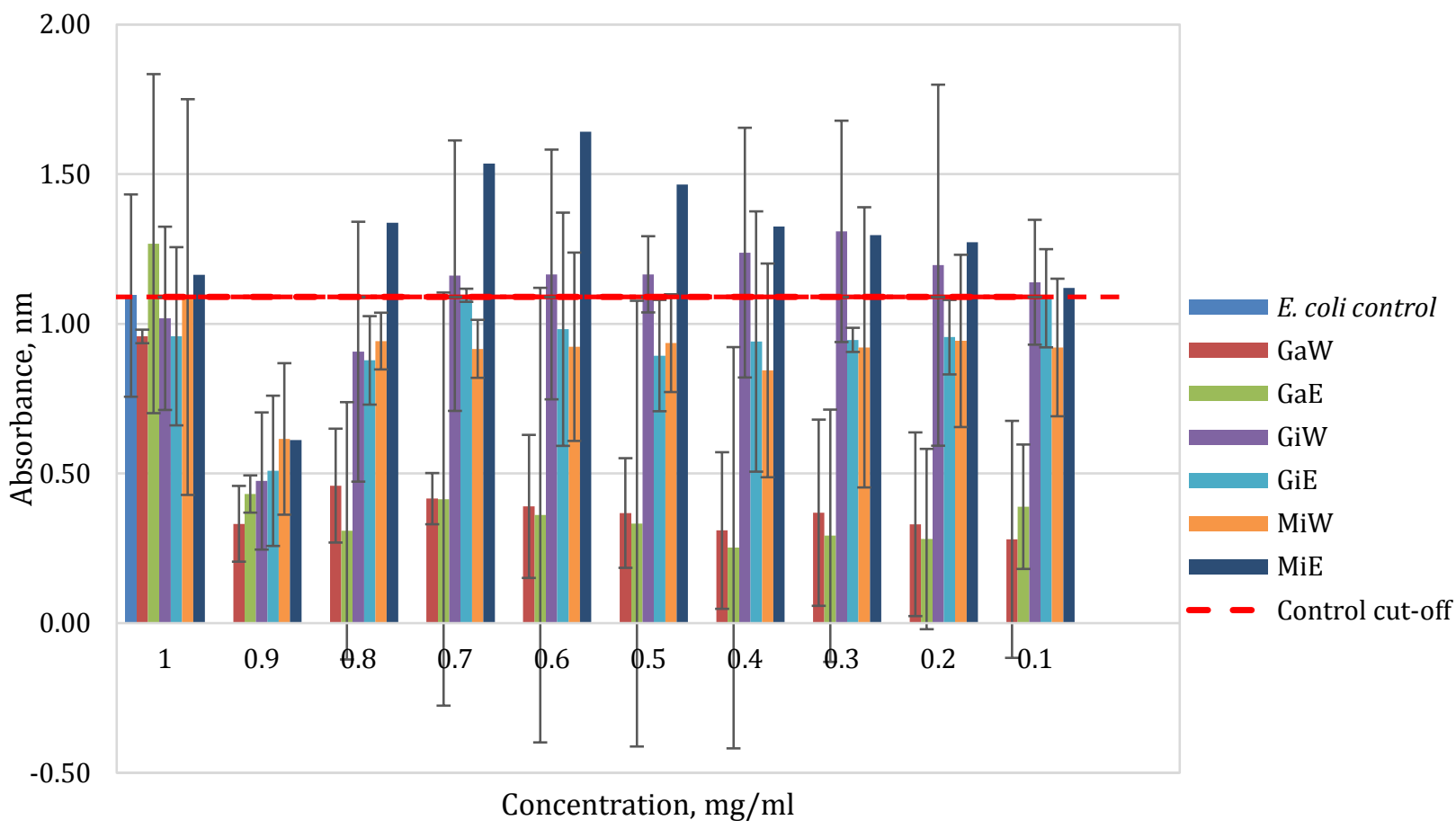

Figure 2: The antibiofilm effects of water and ethanol extracts from garlic, ginger and mint on the E. coli at concentrations between $(0.1 \mathrm{mg} / \mathrm{ml}-1 \mathrm{mg} / \mathrm{ml})$ incubation at $25^{\circ} \mathrm{C}$

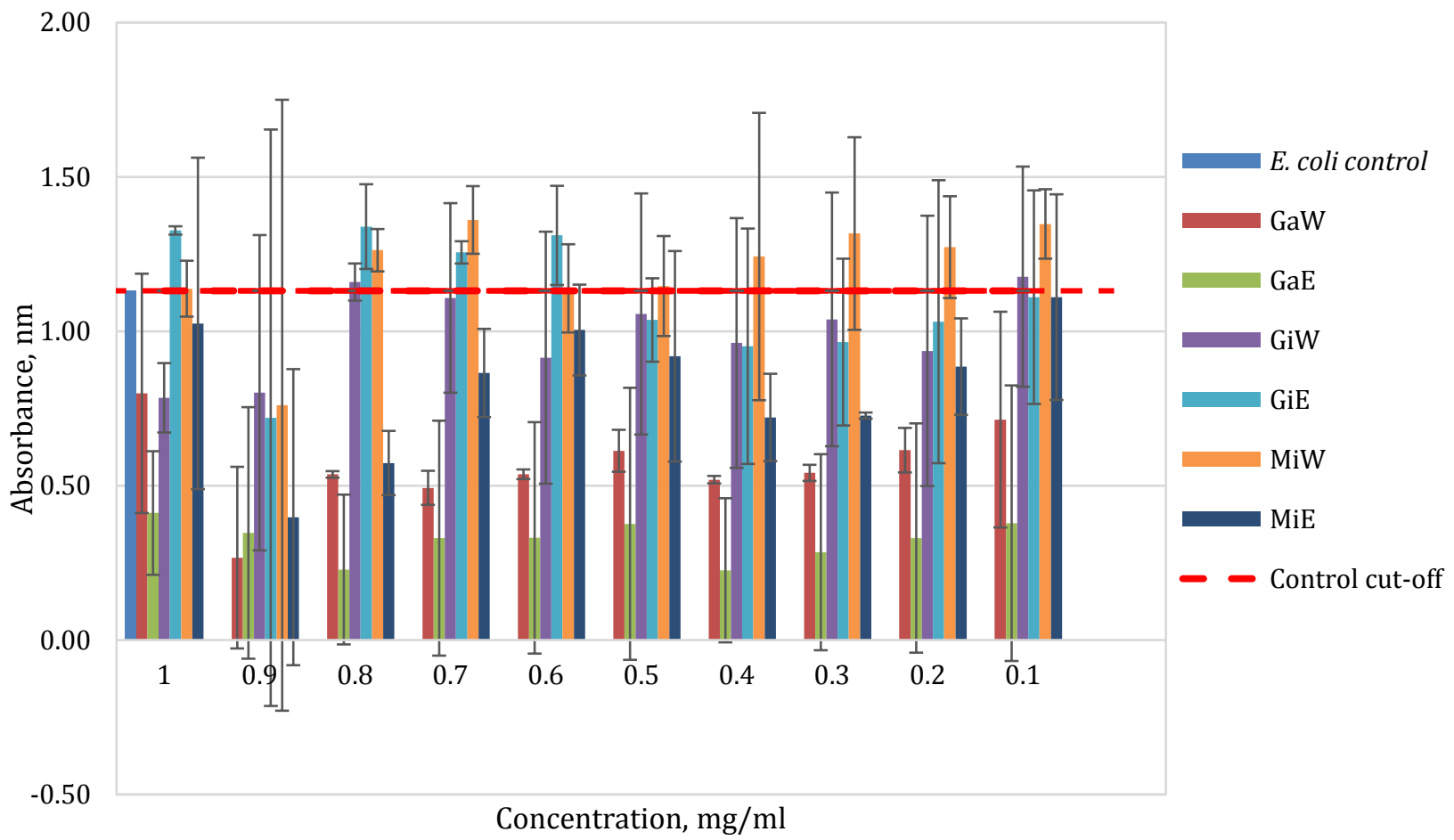

Figure 3: The antibiofilm effects of water and ethanol extracts from garlic, ginger and mint on the E. coli at concentrations between $(0.1 \mathrm{mg} / \mathrm{ml}-1 \mathrm{mg} / \mathrm{ml})$ incubation at $37{ }^{\circ} \mathrm{C}$. 
The results of this study also showed that some tested extracts had better results in inhibiting biofilm formations. Notably, garlic at both temperatures $\left(25^{\circ} \mathrm{C} \& 37^{\circ} \mathrm{C}\right)$ demonstrated the greatest inhibitory effects against biofilm development at the least concentration tested. Considering that garlic was able to induce biofilm formation at low concentrations $(0.1 \mathrm{mg} / \mathrm{ml})$, it remains unknown whether it can inhibit the growth of $E$. coli biofilms at much lower concentrations than $0.1 \mathrm{mg} / \mathrm{ml}$. Nevertheless, numerous studies have stressed that antimicrobial and antibiofilm activity may positively be associated with the synergy effects between all components e.g. flavonoids, essential oils and not only due to a single compound (Agarwal et al. 2008; Adukwu et al. 2012; Singh et al. 2015).

\section{Antibiofilm activity}

Biofilm criterion $(>0.2$ (A590-630) is vital to establish whether the cells formed biofilms (Narisawa, Furukawa et al. 2005). Figures 2 and 3 illustrate the percentages of the antibiofilm effects of water and ethanol extracts from garlic, ginger and mint on the E. coli at $25^{\circ} \mathrm{C}$ and $37^{\circ} \mathrm{C}$, while Figure 4 summarises the percentages of inhibition. The figures show that ethanol extract of ginger was the least effective at $37^{\circ} \mathrm{C}$ as it only inhibited $2.1 \%$ of E. coli biofilms from forming. Both garlic extracts plus ginger water could inhibit more than $50 \%$ of the E. coli biofilms from forming. It was clarified that the E. coli biofilm in each well plate was comprised of more than $10^{6}$ cells/well. As shown in Figure 2-4, E. coli was able to form biofilms at both experimented temperatures; $25^{\circ} \mathrm{C}$ and $37^{\circ} \mathrm{C}$, with $37^{\circ} \mathrm{C}$ having the highest number of cells of 2.53 (A620) which is approximately $10^{9}$ cells/well. On the other hand, the absorbance at $23^{\circ} \mathrm{C}$ was 1.36 (A620), which is about $10^{8}$ cells/well. Contrary to previous reports (Szabó et al. 2005; White-Ziegler et al. 2008; Vejborg and Klemm 2009), this study did not find greater biofilm formation at the lower temperature $\left(25^{\circ} \mathrm{C}\right)$. It has been reported that curli expression is best at temperatures below $30^{\circ} \mathrm{C}$ (Barnhart and Chapman 2006) which could potentially boost the bacteria's attachments to surfaces and generate biofilms (Van Houdt and Michiels 2005). Moreover, it has been widely acknowledged that temperature serves as a cue to control gene expression in $E$. coli and other microorganisms. Also, (Castonguay et al. 2006) assert that the main determinant affected by temperature could be the curli.

It has been advised that high temperatures $\left(37^{\circ} \mathrm{C}\right)$ increase hydrophobicity which may enhance initial cell adherence, contributing to a greater biofilm density (Sandasi et al. 2008). Additionally, $37^{\circ} \mathrm{C}$ is the best growth temperature for E. coli hence, it is no surprise that the bacteria formed more biofilms at $37^{\circ} \mathrm{C}$ compared to $25^{\circ} \mathrm{C}$. Moreover, this increases cell population which then results in a higher degree of initial attachment. As temperature increases metabolic rates increases which potentially promotes enzyme activities. (Villanueva et al. 2011) outlined that a slight increase of $3^{\circ} \mathrm{C}$ in temperature could impact biofilm formation. The current study's findings suggest that $E$. coli's feeble ability to form biofilms at $25^{\circ} \mathrm{C}$ could be attributed to the longer lag phase, which can be approximately one to two hours. Incubation at $25^{\circ} \mathrm{C}$ and $37^{\circ} \mathrm{C}$ for 48 hours also confirmed previous findings (Silhan et al. 2006) that temperature increases biofilm growth. However, it is acknowledged that there are considerable discussions among researchers on the probable impacts of temperature on biofilm formation and growth.

Garlic extracts demonstrated the strongest inhibitory effects against $E$. coli at both temperatures. The results indicated that a minimum amount of $0.1 \mathrm{mg} / \mathrm{ml}$ at $37^{\circ} \mathrm{C}$ of the garlic extract is needed whereas, at $25^{\circ} \mathrm{C}, 0.4$ and $1 \mathrm{mg} / \mathrm{ml}$ is required to inhibit $50 \%$ of the biofilm population. Other tested extracts required a significantly higher concentration $(0.9 \mathrm{mg} / \mathrm{ml})$ and the mint extract showed that a much higher concentration is required to inhibit $50 \%$ of the biofilm growth. At the concentration of $0.9 \mathrm{mg} / \mathrm{ml}$, the mint preparations were only able to inhibit about $43.8 \pm 0.2 \%$ of the biofilm formation. At $25^{\circ} \mathrm{C}$, ginger and mint did not inhibit 50\% biofilm growth.

This study observed that biofilm inhibition mostly occurred at high concentrations. The results presented here can be related to the noticeable differences between the planktonic cells' MIC and the BIC50. Specifically, ginger and mint lucidly showed limited or no activity against biofilm formation at its highest concentration plus, and it was unable to inhibit $50 \%$ of biofilm development. 


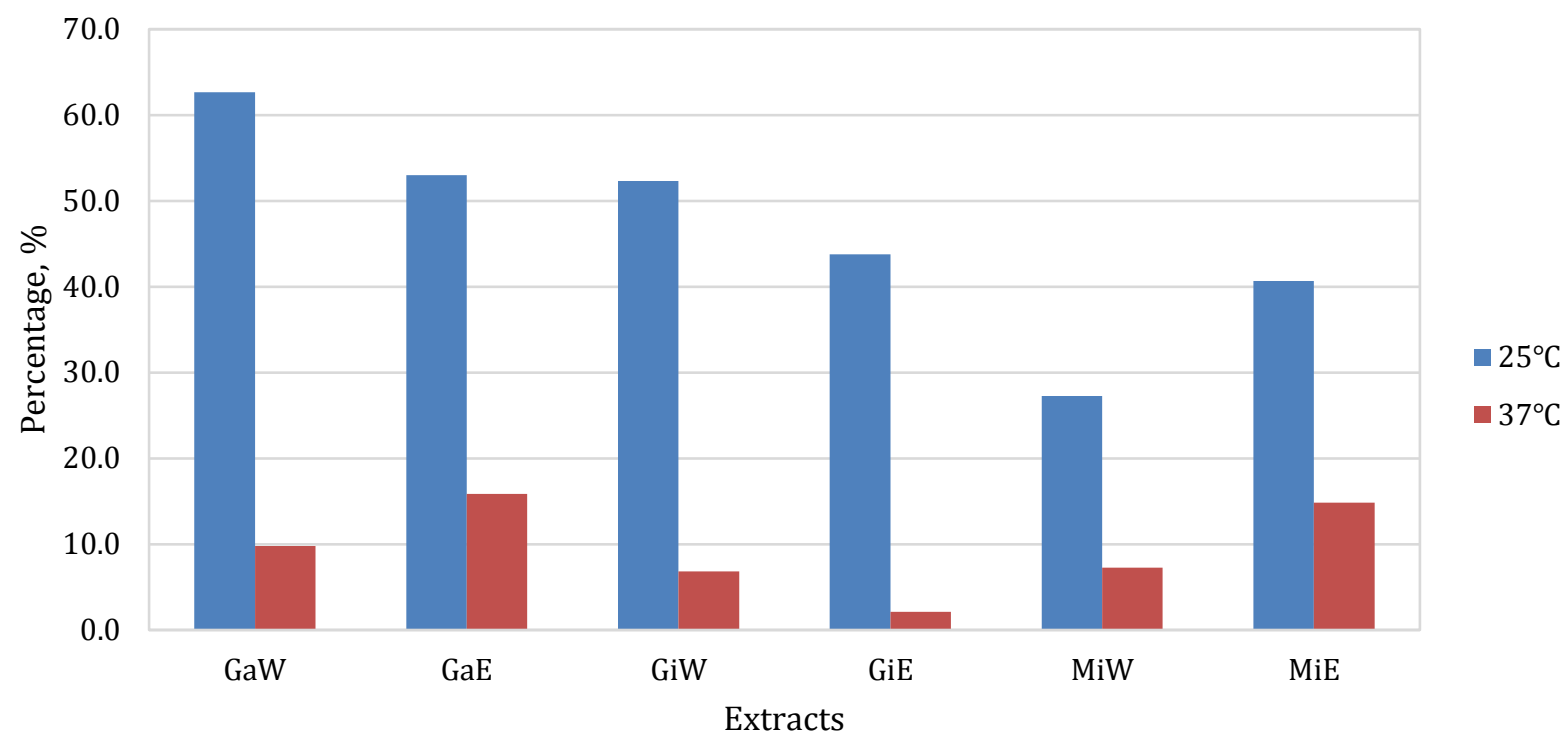

Figure 4: The percentages of the antibiofilm effects of water and ethanol, extracts from garlic, ginger and mint against $E$. coli at $25^{\circ} \mathrm{C}$ and $37^{\circ} \mathrm{C}$

Several studies concluded that biofilms' reduced metabolic activity might justify their resistance to antimicrobial agents (Mah and O'Toole 2001; Sandasi et al. 2008). Moreover, this could also suggest unsatisfactory concentrations and or absence of the antibiofilm active components. The ineffectiveness of antimicrobial compounds to reduce biofilm formation at low concentrations $<25$ $\mu \mathrm{g} / \mathrm{ml}$ has been previously reported (Ceylan et al. 2014) and the results obtained agrees with previous studies (Sandasi et al. 2010; John et al. 2013; Bazargani and Rohloff 2016).

Furthermore, as biofilms develop, the initial cells experience attachment, resulting in maturation. Their removal at this stage is said to be challenging and would at times require mechanical force or chemical disruption (Valeriano et al. 2012). Surprisingly, the study observed an increase in $E$. coli biofilms' metabolic activity in the presence of the extracts. The reasons for such increases in metabolic activity are unknown. However, (Kwieciński et al. 2009) reported an increase in $S$. aureus biofilms' metabolic activity, when treated with Tea Tree Oil (TTO) concentrations lower than the minimum biofilm inhibitory concentration, which articulated that it could be a result of a stress response. Whether this is the case for the increase in
E. coli biofilms' metabolic activity when formed in the tested extracts remains to be determined.

The garlic extracts demonstrated the strongest inhibitory effects against $E$. coli at both temperatures. The results indicated that a minimum amount of $0.1 \mathrm{mg} / \mathrm{ml}$ at $37^{\circ} \mathrm{C}$ of the garlic extract is needed whereas, at $25^{\circ} \mathrm{C}, 0.4 \& 1 \mathrm{mg} / \mathrm{ml}$ is required to inhibit $50 \%$ of the biofilm population. Other tested extracts required a significantly higher concentration $(0.9 \mathrm{mg} / \mathrm{ml})$ and the mint extract showed that a much higher concentration is required to inhibit $50 \%$ of the biofilm growth. At the concentration of $0.9 \mathrm{mg} / \mathrm{ml}$, the mint preparations were only able to inhibit about $43.8 \pm 0.2 \%$ of the biofilm formation. At $25^{\circ} \mathrm{C}$, ginger and mint did not inhibit $50 \%$ biofilm growth.

\section{Conclusions}

This study's overall objective was to elucidate better the antimicrobial and antibiofilm effects of garlic, ginger, and mint against $E$. coli biofilms. The study found that garlic, ginger and mint have a wide array of antimicrobial and antibiofilm activity against the tested bacteria. The garlic extracts proved to be the most effective amongst the tested extracts, and this has been credited to the presence of its active compound Allicin. Looking forward, this provides 
a good starting point for in vivo studies and industrial trials to determine the antibiofilm concentration of extracts in detergents. Importantly, this study also provided evidence that lower temperature induces biofilm formation. E. coli has become of high importance to health issues. There is a need to conduct more studies and demand an upgraded Hazard Analysis Critical Control Points (HACCP) with biofilm assessments in food plants to provide clearer information on possible contamination. Therefore, this study demands further analysis of the application of food extracts in food safety cleaning systems to ensure public health and well-being.

\section{Authors Contributions}

NNKH conducted experiments. HO analysed the data. AA and OCE was involved in the preparation of the manuscript. CA reviewed and updated the manuscript. All authors read and approved the manuscript.

Funding: Funding was provided by the Chevening Scholarships, the UK government's global scholarship programme, funded by the Foreign and Commonwealth Office (FCO) and partner organisations, as part of the MSc programme.

\section{References}

Adukwu E, Allen SC, Phillips CA. The anti- biofilm activity of lemongrass (Cymbopogon flexuosus) and grapefruit (Citrus paradisi) essential oils against five strains of Staphylococcus aureus. Journal of Applied Microbiology, 2012, 113(5), 1217-1227. https://doi.org/10.1111/j.1365-2672.2012.05418.x

Agarwal V, Lal P, Pruthi V. Prevention of Candida albicans biofilm by plant oils. Mycopathologia, 2008, 165(1), 13-19. https://doi.org/10.1007/s11046007-9077-9

Al-Sum BA, Al-Arfaj AA. Antimicrobial activity of the aqueous extract of mint plant. Science Journal of Clinical Medicine, 2013, 2(3), 110-113. https://doi.org/10.11648/j.sjcm.20130203.19

Ankri S, Mirelman D. Antimicrobial properties of allicin from garlic. Microbes and Infection, 1999, 1(2), 125-129. https://doi.org/10.1016/S12864579(99)80003-3

Bakht J, Muhammad T, Ali H, Islam A, Shafi M. Effect of different solvent extracted sample of Allium sativum (Linn) on bacteria and fungi. African Journal of Biotechnology, 2011, 10(31), 5910-5915. https://doi.org/10.5897/AJB11.232

Bakri I, Douglas C. Inhibitory effect of garlic extract on oral bacteria. Archives of Oral Biology, 2005, 50(7), 645-651. https://doi.org/10.1016/j.archoralbio.2004.12.002

Barnhart MM, Chapman MR. Curli biogenesis and function. Annual Review of Microbiology, 2006, 60, 131-147.

https://doi.org/10.1146/annurev.micro.60.080805.14 $\underline{2106}$

Bayer A, Kirby W, Sherris J, Turck M. Antibiotic susceptibility testing by a standardized single disc method. American Journal of Clinical Pathology, 1966, 45(4), 493-496. https://doi.org/10.1093/ajcp/45.4 ts.493

Bazargani MM, Rohloff J. Antibiofilm activity of essential oils and plant extracts against Staphylococcus aureus and Escherichia coli biofilms. Food Control, 2016, 61, 156-164. https://doi.org/10.1016/j.foodcont.2015.09.036

Block E. The chemistry of garlic and onions. Scientific American, 1985, 252(3), 114-121. https://doi.org/10.1038/scientificamerican0385-114

Castonguay M-H, Van der Schaaf S, Koester W, Krooneman J, Van der Meer W, Harmsen H, Landini P. Biofilm formation by Escherichia coli is stimulated by synergistic interactions and coadhesion mechanisms with adherence-proficient bacteria. Research in Microbiology, 2006, 157(5), 471-478. https://doi.org/10.1016/j.resmic.2005.10.003

Cavallito CJ, Bailey JH. Allicin, the antibacterial principle of Allium sativum. I. Isolation, physical properties and antibacterial action. Journal of the American Chemical Society, 1944, 66(11), 19501951. https://doi.org/10.1021/ja01239a048

Ceylan O, Ugur A, Sarac N, Sahin MD. The antimicrobial and antibiofilm activities of Mentha $x$ piperita L. essential oil. Journal of BioScience \& Biotechnology, 2014. http://www.jbb.uniplovdiv.bg/documents/27807/728057/SE-2014-2327.pdf

Chaieb K, Kouidhi B, Jrah H, Mahdouani K, Bakhrouf A. Antibacterial activity of Thymoquinone, an active principle of Nigella sativa and its potency to prevent bacterial biofilm formation. BMC Complementary and Alternative Medicine, 2011, 11(1), 1-6. http://www.biomedcentral.com/1472-6882/11/29

Cos P, Tote K, Horemans T, Maes L. Biofilms: an extra hurdle for effective antimicrobial therapy. Current Pharmaceutical Design, 2010, 16(20), 2279-2295. https://doi.org/10.2174/138161210791792868 
Donlan RM. Biofilms: microbial life on surfaces. Emerging Infectious Diseases, 2002, 8(9), 881. https://doi.org/10.3201/eid0809.020063

Ekwenye U, Elegalam N. Antibacterial activity of ginger (Zingiber officinale) roscoe and garlic (Allium sativum) extracts on Escherichia coli and Salmonella typhi. 2005.

http://docsdrive.com/pdfs/medwelljournals/ijmmas/2 005/411-417.pdf

Galie S, García-Gutiérrez C, Miguélez EM, Villar CJ, Lombó F. Biofilms in the food industry: health aspects and control methods. Frontiers of Microbiology, 2018, 9:898. https://doi.org/10.3389/fmicb.2018.00898

Gull I, Saeed M, Shaukat H, Aslam SM, Samra ZQ, Athar AM. Inhibitory effect of Allium sativum and Zingiber officinale extracts on clinically important drug resistant pathogenic bacteria. Annals of Clinical Microbiology and Antimicrobials, 2012, 11(1), 1-6. https://doi.org/10.1007/s002530100722

Harris J, Cottrell S, Plummer S, Lloyd D. Antimicrobial properties of Allium sativum (garlic). Applied Microbiology and Biotechnology, 2001, 57(3), 282286. https://doi.org/10.1007/s002530100722

Iwalokun B, Ogunledun A, Ogbolu D, Bamiro S, JimiOmojola J. In vitro antimicrobial properties of aqueous garlic extract against multidrug-resistant bacteria and Candida species from Nigeria. Journal of Medicinal Food, 2004, 7(3), 327-333.

http://www.sld.cu/galerias/pdf/sitios/mednat/in_vitro antimicrobial_properties_of_aqueous_garlic_extrac t against multidrug-resistant bacteria.pdf

Jang H-J, Lee H-J, Yoon D-K, Ji D-S, Kim J-H, Lee CH. Antioxidant and antimicrobial activities of fresh garlic and aged garlic by-products extracted with different solvents. Food Science Biotechnology, 2018, 27(1), 219-225. https://doi.org/10.1007/s10068-017-0246-4

John N.R, Gala V.C, Sawant C.S. Inhibitory effects of plant extracts on multi-species dental biofilm formation in vitro. International Journal of Pharmacy and Biological Science, 2013, 4(2), 487495.

Kwieciński J, Eick S, Wójcik K. Effects of tea tree (Melaleuca alternifolia) oil on Staphylococcus aureus in biofilms and stationary growth phase. International Journal of Antimicrobial Agents, 2009, 33(4), 343-347. https://doi.org/10.1016/j.ijantimicag.2008.08.028

Lee J-H, Cho HS, Joo SW, Chandra Regmi S, Kim J-A, Ryu C-M, Ryu SY, Cho MH, Lee J. Diverse plant extracts and trans-resveratrol inhibit biofilm formation and swarming of Escherichia coli 0157 : H7. Biofouling, 2013, 29(10), 1189-1203. https://doi.org/10.1007/s10068-017-0246-4
Liu C, Yang X, Yao Y, Huang W, Sun W, Ma Y. Determination of antioxidant activity in garlic (Allium sativum) extracts subjected to boiling process in vitro. Journal of Food and Nutrition Research, 2014, 2(7), 383-387. https://doi.org/10.12691/jfnr-2-7-9

Mah T-FC, O'Toole GA. Mechanisms of biofilm resistance to antimicrobial agents. Trends in Microbiology, 2001, 9(1), 34-39. https://doi.org/10.1016/S0966-842X(00)01913-2

Malu S, Obochi G, Tawo E, Nyong B. Antibacterial activity and medicinal properties of ginger (Zingiber officinale). Global Journal of Pure and Applied Sciences, 2009, 15(3-4). https://doi.org/10.4314/gjpas.v15i3-4.48561

Mendonça RCS, Morelli AMF, Pereira JAM, de Carvalho MM, de Souza NL. Prediction of Escherichia coli O157: $\mathrm{H} 7$ adhesion and potential to form biofilm under experimental conditions. Food Control, 2012, 23(2), 389-396. https://doi.org/10.1016/j.foodcont.2011.08.004

Modarresi-Chahardehi A, Ibrahim D, Fariza-Sulaiman S, Mousavi L. Screening antimicrobial activity of various extracts of Urtica dioica. Revista de Biologia Tropical, 2012, 60(4), 1567-1576. https://doi.org/10.1016/j.foodcont.2011.08.004

Narisawa N, Furukawa S, Ogihara H, Yamasaki M. Estimation of the biofilm formation of Escherichia coli K-12 by the cell number. Journal of Bioscience and Bioengineering, 2005, 99(1), 78-80.

Natta L, Orapin K, Krittika N, Pantip B. Essential oil from five Zingiberaceae for anti food-borne bacteria. International Food Research Journal, 2008, 15(3), 337-346. https://doi.org/10.1263/jbb.99.78

Nikolić M, Vasić S, Đurđević J, Stefanović O, Čomić L. Antibacterial and anti-biofilm activity of ginger (Zingiber officinale (Roscoe)) ethanolic extract. Kragujevac Journal of Science, 2014(36), 129-136. https://doi.org/10.5937/kgjsci1436129n

Nostro A, Guerrini A, Marino A, Tacchini M, Di Giulio M, Grandini A, Akin M, Cellini L, Bisignano G, Saraçoğlu HT. In vitro activity of plant extracts against biofilm-producing food-related bacteria. International Journal of Food Microbiology, 2016, 238, 33-39.

https://doi.org/10.1016/j.ijfoodmicro.2016.08.024

O'Gara EA, Hill DJ, Maslin DJ. Activities of garlic oil, garlic powder, and their diallyl constituents against Helicobacter pylori. Applied Environmental Microbiology, 2000, 66(5), 2269-2273. https://www.ncbi.nlm.nih.gov/pmc/articles/PMC101 489/pdf/am002269.pdf

Ryu J-H, Beuchat LR. Biofilm formation by Escherichia coli O157: H7 on stainless steel: effect of exopolysaccharide and curli production on its 
resistance to chlorine. Applied Environmental Microbiology, 2005, 71(1), 247-254. https://doi.org/10.1128/AEM.71.1.247-254.2005

Ryu J-H, Kim H, Beuchat LR. Attachment and biofilm formation by Escherichia coli O157: H7 on stainless steel as influenced by exopolysaccharide production, nutrient availability, and temperature. Journal Food Protection, 2004, 67(10), 2123-2131.

Sandasi M, Leonard C, Viljoen A. The effect of five common essential oil components on Listeria monocytogenes biofilms. Food Control, 2008, 19(11), 1070-1075. https://doi.org/10.1016/j.foodcont.2007.11.006

Sandasi M, Leonard C, Viljoen A. The in vitro antibiofilm activity of selected culinary herbs and medicinal plants against Listeria monocytogenes. Lett Applied Microbiology, 2010, 50(1), 30-35. https://doi.org/10.1111/j.1472-765X.2009.02747.x

Sarker SD, Nahar L, Kumarasamy Y. Microtitre platebased antibacterial assay incorporating resazurin as an indicator of cell growth, and its application in the in vitro antibacterial screening of phytochemicals. Methods, 2007, 42(4):321-324. https://doi.org/10.1016/j.ymeth.2007.01.006

Sebiomo A, Awofodu A, Awosanya A, Awotona F, Ajayi A. Comparative studies of antibacterial effect of some antibiotics and ginger (Zingiber officinale) on two pathogenic bacteria. Journal of Microbiology and Antimicrobials, 2011, 3(1), 18-22.

https://academicjournals.org/journal/JMA/articleabstract/0864D829693

Shi X, Zhu X. Biofilm formation and food safety in food industries. Trends Food Science Technology, 2009, 20(9), 407-413. https://doi.org/10.1016/j.tifs.2009.01.054

Shilpa S, Thomas R. Antimicrobial properties of Allium sativum (garlic) against commonly encountered gastrointestinal pathogens. Advances in Plant Sciences, 2010, 23(2):387-389.

Silhan J, Corfitzen CB, Albrechtsen H-J. Effect of temperature and pipe material on biofilm formation and survival of Escherichia coli in used drinking water pipes: a laboratory-based study. Water Science and Technology, 2006, 54(3), 49-56.

Simões M, Simões LC, Vieira MJ. A review of current and emergent biofilm control strategies. LWT-Food Science Technology, 2010, 43(4), 573-583. https://doi.org/10.1016/j.lwt.2009.12.008

Singh R, Shushni MA, Belkheir A. Antibacterial and antioxidant activities of Mentha piperita L. Arabian Journal of Chemistry, 2015, 8(3), 322-328. https://doi.org/10.1016/j.arabjc.2011.01.019

Sivropoulou A, Kokkini S, Lanaras T, Arsenakis M. Antimicrobial activity of mint essential oils. Journal of Agriculture Food Chemistry, 1995, 43(9), 2384-
2388. Retrieved from:

https://pubs.acs.org/sharingguidelines

Szabó E, Skedsmo A, Sonnevend A, Al-Dhaheri K, Emödy L, Usmani A, Pal T. Curli expression of enterotoxigenic Escherichia coli. Folia

Microbiology, 2005, 50(1), 40.

https://doi.org/10.1007/BF02931292

Trachoo N. Biofilms and the food industry. Biofilms, 2003, 25(6), 808.

Valeriano C, De Oliveira TLC, De Carvalho SM, das Graças Cardoso M, Alves E, Piccoli RH. The sanitizing action of essential oil-based solutions against Salmonella enterica serotype Enteritidis S64 biofilm formation on AISI 304 stainless steel. Food Control, 2012, 25(2), 673-677. https://doi.org/10.1099/mic.0.026419-0

Van Houdt R, Michiels CW. Role of bacterial cell surface structures in Escherichia coli biofilm formation. Research in Microbiology, 2005, 156(56), 626-633. https://doi.org/10.1016/j.resmic.2005.02.005

Vejborg RM, Klemm P. Cellular chain formation in Escherichia coli biofilms. Microbiology, 2009, 155(5), 1407-1417. https://doi.org/10.1099/mic.0.026419-0

Villanueva VD, Font J, Schwartz T, Romani AM. Biofilm formation at warming temperature, acceleration of microbial colonization and microbial interactive effects. Biofouling, 2011, 27(1), 59-71. https://doi.org/10.1080/08927014.2010.538841

White-Ziegler CA, Um S, Perez NM, Berns AL, Malhowski AJ, Young S. Low temperature (23 C) increases expression of biofilm-, cold-shock-and RpoS-dependent genes in Escherichia coli K-12. Microbiology, 2008, 154(1), 148-166. https://doi.org/10.1099/mic.0.2007/012021-0

WHO Estimates of the Burden of foodborne disease http://www.who.int/foodsafety/areas_work/foodborn e-diseases/ferg/en/

Wolde T, Kuma H, Trueha K, Yabeker A. Anti-bacterial activity of garlic extract against human pathogenic bacteria. Journal of Pharmacovigilance, 2018, 6(1), 1-5. https://doi.org/10.4172/2329-6887.1000253 